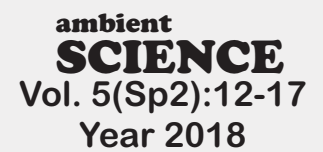

\title{
Status and Diversity of Wetland Birds at Ancient Township Ratanpur of Chhattisgarh, India
}

\section{Devendra Singh Porte*, Seema Gupta}

Department of Zoology, Govt. Nagarjuna P.G. College of Science, Raipur - 492010, India

Study Area: Ratanpur, Chhattisgarh, India Coordinates: $85^{\circ} 17^{\prime} \mathrm{E} ; 2^{2}{ }^{\circ} 3^{\prime} \mathrm{N}$

Key words: Avifauna, Seasonal distribution, Biodiversity, Degraded water bodies

\section{Introduction:}

Birds are the omnipresent fauna that occupies both terrestrial and wetland ecosystems. Wetlands could not be referred to a complete terrestrial or aquatic body. According to Ramsar convention wetland are "submerged or water saturated land, both natural and man-made, permanent or temporary filled, that is static or flowing, fresh, brackish or salt including areas of marine water". They are the vital habitats for residential as well as migratory birds for foraging, roosting and breeding activities (Gibbs, 1993; Paracuellos, 2006). Wetland constitutes a treasury of biodiversity. These are complex water and land interactive system and compose $6 \%$ of earth land surface (Urfi et al., 2005). These are supposed to be the most fertile and productive site in the world but ecologically fragile, liable to degradation and degeneration under the prevailing anthropogenic pressure (Deshkar et al., 2010). Approximately three hundred and ten wetland bird species are recorded in India (Kumar \& Gupta, 2009). Total $50 \%$ of these are migratory and visit India from the colder regions of China, Russia, Central Asia, Tibet and the Himalayan region.

\section{Abstract}

Wetlands are important habitat for native as well as migratory water birds especially for roosting, foraging and breeding activities. The present study area, Ratanpur (Chhattisgarh) has many natural and man-made water bodies which play an important role not only for agricultural uses but also for resident bird fauna of the region. An avifaunal survey carried out on ten selected wetlands of Ratanpur for two consecutive years viz., 2013 and 2014 for evaluating the diversity, distribution, and status. The result of the study revealed presence of 4572 wetland birds of 29 species belonging to 12 families and 7 orders. Ciconiiformes was the dominant order with nine species whereas family Ardeidae had the highest diversity. The census revealed that two specif ic ponds provided the most congenial habitat for many wetland avian species as they harbored 1707 and 1375 birds respectively. The study revealed that the ponds which were sacred or away from the human communities were harbour relatively large number of avian species while the pond situated near settlement areas or were polluted showed less diversity and were specifically occupied by residential heronry birds.

The diversity of birds is one of the most significant environmental indicators for determining the health of the habitats. The degradation of wetlands affects the bird population and the diversity. So, there is a necessity for the assessment of wetlands for birds as an ideal habitat. India has 27403 large wetland of which 23444 are inland (Ramamurthy \& Rajakumar, 2014). Apart from natural wetlands, which support twenty percent of the known diversity (Deepa \& Ramchandran, 1999), there are many man-made wetlands, such as dams, ponds etc. These artif icial wetlands can provide suitable habitats for water birds (Paracuellos \& Telleria, 2004; Okes et al., 2008; Rendon et al., 2008). Day by day, globally the interest in the conservation of water birds and their wetlands habitats which are under threat of extinction due to anthropological activities and unfavorable environmental conditions (Froneman et al., 2001) are increasing. As per Rosser \& Mainka (2002) 12\% of the avian species are threatened for extinction throughout the world.

The study area, Ratanpur is a small township in Bilaspur district, Chhattisgarh, India. The town has many temples and ponds which attract a huge number of tourists

*Corresponding Author: portedevendra26@gmail.com 


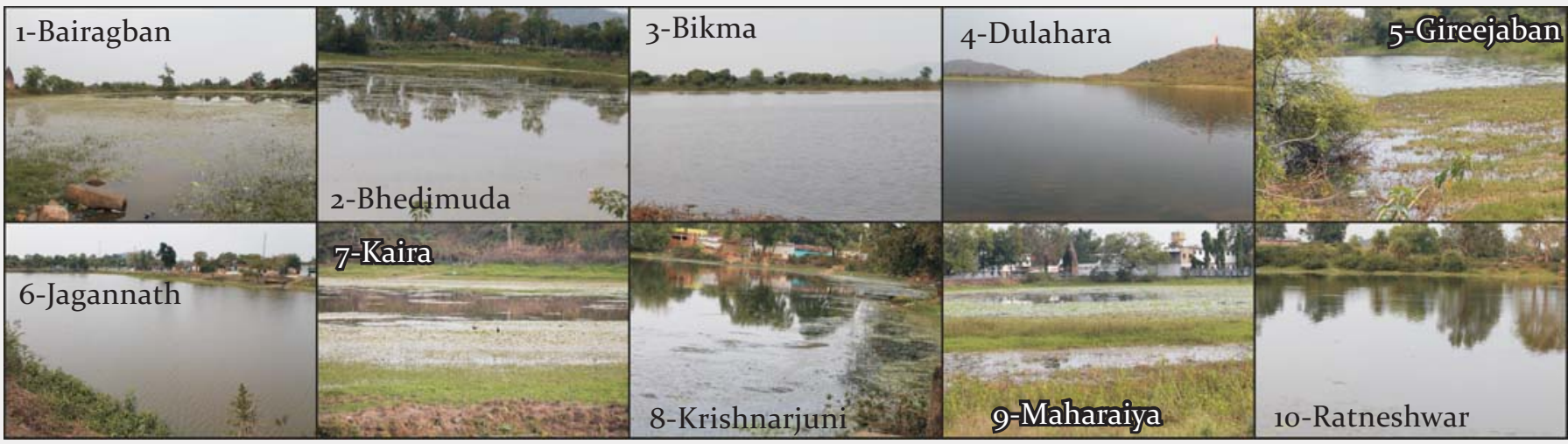

Plate-1: Ten water bodies (wetland/Ponds): our study sites

from far and wide places throughout the year. Due to human encroachment and anthropological activities, this area is facing a serious problem of land and water pollution and so the avifauna. Therefore, a study on aspects like distribution, diversity, ecology and other activities of birds become very important. Till date, information on the ecological aspects of avifauna in Chhattisgarh state was very limited (Majumdar, 1984; Chandra \& Singh, 2004; Sharma et al., 2014; Vishwakarma et al., 2014, Sangode et al., 2015; Chandra et al., 2015; Vishwakarma, 2015). However, the information regarding the bird fauna of Ratanpur is completely lacking. Hence, this study was planned to assess the diversity, distribution and status of wetland birds in ten different ponds of Ratanpur.

\section{Materials and methods:}

Study site: Ratanpur is located about $25 \mathrm{Km}$ away from the district Bilaspur of state Chhattisgarh, India and famous for its historical and religious importance. It is situated at an elevation of $306 \mathrm{~m}$ from the sea level. It harbours more than a hundred small and large ponds abound with agricultural fields and numerous big trees. The water bodies are used for irrigation purposes and also by the people for their daily needs. Ten perennial ponds viz., Bairagban, Bhedimuda, Bikma, Dulahara, Gireejaban, Jagannath temple, Kaira, Krishnarjuni, Maharaiya and Ratneshwar ponds were selected for the study (Plate-1). Bairagban, Bikma, Dulahara, Gireejaban, Jagannath and Maharaiya pond are sacred pond whereas, Bhedimuda, Kaira, Krishnarjuni and Ratneshwar ponds are situated close to human settlements and were polluted, filled with garbage and affected by anthropogenic practices at the time of the study.

Data collection: We visited the study site twice a week, during the summer, rainy and winter seasons of the year, in order to cover migratory and resident species. Survey was conducted by using distance sampling point count method (Buckland et al., 2004) to observe the bird diversity, distribution in all the selected ten wetlands for two consecutive years (2013 to 2014). The field characteristics were noted down on the ornithological data sheet. Whenever required, photographs were taken using a Digital Camera with a suitable zoom lens. Bird survey was conducted from o6:00 to 10:00 hrs and from 16:0o to 19:0o hrs. The recorded wetland birds were identified by following Ali \& Ripley (1995), Ali (2003), Hossain et al. (2004), Kumar et al. (2006) and Grimmett et al. (2006). The Checklist was prepared using common and scientific name following Manakadan \& Pittie (2001). The status of bird population was categorized as VC (very common), C (common), NR (not rare), R (rare), SV (summer visitor), MV (monsoon visitor), WV (winter visitor), LC (least concern) and NT (near threatened) based on observations during the study following IUCN criteria (2014). The data collected during the study period were analyzed using Biodiversity Pro (version-2) Statistical Software.

\section{Results :}

During the study period (Jan. 2013 to Dec. 2014), a total of ten wetlands in Ratanpur were surveyed and 4572 wetland birds of 29 species belonging to twelve families from seven orders were tabulated (Table-1). Among the seven orders, Ciconiiformes dominated with nine species constituting $31.03 \%$ of the total species whereas Podicipediformes contributed as lowest with only one species (3.44\%). Among 12 families, Ardeidae dominated with eight species constituting 27.58\%, whereas Charadridae, Ciconiidae, Podicipedidae, Recurvirostridae, Rostratulidae, and Scolopacidae represented with one species each constituted 3.44\%.

Dulahara and Bikma pond harbored 1707 and 1375 individual of bird respectively. Maharaiya and Bairaagban ponds also favored wetland avian fauna with 463 and 431 birds respectively (Table 2 ). The minimum number of water birds was found in Rataneshwar wetland (32). Similarly, the highest number of species occurred in Bikma pond (28) followed by Dulahara( 27), Maharaiya (19), Bairagban (18), Jagannath (10), Bhedimuda, Gireejaban and Ratneshwar (9 species each) and the minimum number of species were recorded from Kaira (8) and Krishnarjuni (6). Among 29 species, one species, 
RESEARCH ARTICLE

Ferruginous pochard, Aythya nyroca was near threatened species according to IUCN red list and rest twenty eight species were least concerned (Table-1). Individuals of family Ardeidae were the dominating birds in the wetlands of Ratanpur. Aythya nyroca is a winter visitor and was noticed in Dulahara and Bikma wetland (Table-2).

Table-1: Avian species recorded from various wetlands of Ratanpur area during Jan.2013 to Dec.2014

\begin{tabular}{|c|c|c|c|}
\hline Scientific Name & Common Name & $\mathrm{I}^{*}$ & $M^{*}$ \\
\hline Order-Anseriformes (13.79\%) & \multicolumn{2}{|c|}{ Family-Anatidae } & \\
\hline Anas strepera & Gadwall & LC & WV \\
\hline Aythya nyroca & Ferruginous pochard & NT & WV \\
\hline Dendrocygna javanica & Lesser Whistling Duck & $\mathrm{LC}$ & WV \\
\hline Nettapus coromandelianus & Cotton Pigmy Goose & $\mathrm{LC}$ & WV \\
\hline \multicolumn{3}{|c|}{$\begin{array}{l}\text { Order-Charadriiformes }(20.68 \%) \\
\text { Vanellus indicus }\end{array}$} & \\
\hline Vanellus indicus & \multicolumn{3}{|c|}{ Family-Jacanidae } \\
\hline Hydr & Pheasant-tailed Jacana & $\mathrm{LC}$ & WV \\
\hline Metc & Bronze-winged Jacana & \multicolumn{2}{|c|}{ Family-Recurvirostridae } \\
\hline himantopus & \multicolumn{3}{|c|}{$\begin{array}{c}\text { Black-winged Stilt } \quad \text { LC SV } \\
\text { Family-Rostratulidae }\end{array}$} \\
\hline Rost & \multicolumn{3}{|c|}{$\begin{array}{c}\text { Greater Painted-snipe LC } \quad \\
\text { Family-Scolopacidae }\end{array}$} \\
\hline Tringa ochropus & Green Sandpiper & $\mathrm{LC}$ & NR \\
\hline \multicolumn{4}{|c|}{ Order-Ciconiiformes (31.03\%) Family-Ardeidae } \\
\hline Ardea alba & Great White Egret & $\mathrm{LC}$ & $\mathrm{C}$ \\
\hline Ardea & Purple Heron & LC & $\mathrm{R}$ \\
\hline Arde & Indian Pond-heron & $\mathrm{LC}$ & VC \\
\hline Bubulcus ibis & Cattle Egret & $\mathrm{LC}$ & VC \\
\hline Egretta garzet & Little Egret & $\mathrm{LC}$ & $\mathrm{C}$ \\
\hline Ixobrychus cinnamomeus & Chestnut Bittern & $\mathrm{LC}$ & $\mathrm{C}$ \\
\hline Ardea intermedia & Intermediate Egret & $\mathrm{LC}$ & $\mathrm{C}$ \\
\hline Nycticorax nycticorax & $\begin{array}{l}\text { Black-crowned } \\
\text { Night-heron }\end{array}$ & $\mathrm{LC}$ & NR \\
\hline
\end{tabular}

Family-Ciconiidae

Anastomus oscitans Asian Openbill Stork LC MV Order-Coraciiformes (10.35\%) Family-Alcedinidae Alcedo atthis Common Kingfisher LC C Ceryle rudis Pied Kingfisher LC C Halcyon smyrnensis White- breasted LC C Kingf isher

Order-Gruiformes (13.79\%) Family-Rallidae

Amaurornis phoenicurus White Breasted LC R Waterhen

Fulica atra Common Coot LC NR Gallinula chloropus Common Moorhen LC NR Porphyrio porphyrio Purple Swamp Hen LC C Order-Pelecaniformes (6.89\%) Family-Phalacrocoracidae Phalacrocorax carbo Great Cormorant LC R Phalacrocorax niger Little Cormorant LC VC Order-Podicipediformes (3.44\%) Family-Podicipedidae Tachybaptus ruficollis Little Grebe LC WV I*-IUCN Status; $M^{*}$-Migration Status $\mathrm{LC}=$ Least concern, NT $=$ Near threatened, $\mathrm{WV}=$ Winter visitor, $\mathrm{SV}=$ Summer visitor, $\mathrm{MV}=$ Monsoon visitor, $\mathrm{VC}=$ Very common, $\mathrm{C}=$ Common, $\mathrm{NR}=$ Not rare, $\mathrm{R}=$ Rare
Table-2: Season-wise the distribution of birds in wetlands of Ratanpur areaduring Jan.2013 to Dec.2014

\begin{tabular}{|c|c|c|c|c|}
\hline \multirow[t]{2}{*}{ Name of Species } & \multicolumn{3}{|c|}{ Season } & \multirow{2}{*}{$\begin{array}{l}\text { Grand } \\
\text { Total }\end{array}$} \\
\hline & Rain & Winter & Summer & \\
\hline Alcedo atthis & 59 & 20 & 11 & 90 \\
\hline Amaurornis phoenicurus & 68 & 49 & 29 & 146 \\
\hline Anas strepera & $\mathrm{X}$ & 55 & 1 & 56 \\
\hline Anastomus oscitans & 131 & 210 & $\mathrm{X}$ & 341 \\
\hline Ardea alba & 27 & 44 & 11 & 82 \\
\hline Ardea purpurea & 123 & 140 & 5 & 268 \\
\hline Ardeola grayii & 158 & 164 & 198 & 520 \\
\hline Aythya nyroca & $\mathrm{X}$ & 62 & $\mathrm{X}$ & 62 \\
\hline Bubulcus ibis & 175 & 193 & 252 & 620 \\
\hline Ceryle rudis & 6 & 54 & 7 & 67 \\
\hline Dendrocygna javanica & $\mathrm{X}$ & 114 & $\mathrm{X}$ & 114 \\
\hline Egretta garzetta & 43 & 148 & 11 & 202 \\
\hline Fulica atra & $\mathrm{X}$ & 97 & $\mathrm{X}$ & 97 \\
\hline Gallinula chloropus & $\mathrm{X}$ & 31 & 36 & 67 \\
\hline Halcyon smyrnensis & 15 & 50 & 18 & 83 \\
\hline Himantopus himantopus & 8 & $\mathrm{X}$ & 14 & 22 \\
\hline Hydrophasianus chirurgus & $\mathrm{X}$ & 22 & $\mathrm{X}$ & 22 \\
\hline Ixobrychus cinnamomeus & 129 & 74 & 100 & 303 \\
\hline Mesophoyx intermedia & $\mathrm{X}$ & 61 & 9 & 70 \\
\hline Metopedius indicus & 109 & o & 142 & 251 \\
\hline Nettapus coromandelianus & $\mathrm{X}$ & 101 & 20 & 121 \\
\hline Nycticorax nycticorax & o & 181 & 40 & 221 \\
\hline Phalacrocorax carbo & $\mathrm{X}$ & $\mathrm{X}$ & 2 & 2 \\
\hline Phalacrocorax niger & 39 & 45 & 42 & 126 \\
\hline Porphyrio porphyrio & $\mathrm{X}$ & 114 & 144 & 268 \\
\hline Rostratula benghalensis & 22 & 16 & 7 & 45 \\
\hline Tachybaptus ruficollis & $\mathrm{X}$ & 56 & $\mathrm{X}$ & 56 \\
\hline Tringa ochropus & 20 & 36 & 18 & 74 \\
\hline Vanellus indicus & 42 & 34 & 100 & 176 \\
\hline Grand Total & 1174 & 2181 & 1217 & 4572 \\
\hline
\end{tabular}

Seasonal fluctuation in waterbird species: every season has its impact on diversity and density of bird population. The maximum number of waterbirds (2181) was observed in the winter season while a minimum number of waterbirds (1174) was recorded in rainy season. Bubulcus ibis and Ardeola grayii was widely distributed water bird in all the selected wetlands. Ixobrychus cinnamomeus was also widely distributed bird with its density higher in rainy as compared to summer and winter season. Furthermore, Phalacrocorax carbo was reported only in Jagannath pond in the summer season. The population of wetland birds was higher during winter followed by summer and rainy seasons (Fig.-1 \&Table-2).

Species diversity indices: The Shannon index was applied for analysis of wetland avian diversity in ten selected pond of Ratanpur, Chhattisgarh. For the summer season, the maximum Shannon diversity index $\left(\mathrm{H}^{\prime}\right)$ was recorded in Dulahara pond (1.20) (Fig.-2). However, the evenness index (E) was maximum in Gireejaban pond and Ratneshwar pond (0.95) and minimum in Bairagban pond (o.86) (Fig.-3). Shannon diversity index (H') for rainy 
season was recorded highest in Bikma pond (1.08) (Fig.-2). The evenness index (E) for rainy season was maximum in Gireejaban pond and Krishnarjuni pond (o.99) and minimum in Bhedimuda pond (o.89) (Fig.-3). The winter season showed the higher diversity index. The Shannon diversity index $\left(\mathrm{H}^{\prime}\right)$ was higher in Dulahara pond (1.32) and Bikma pond (1.31) as compared to the other ponds (Fig.-2). The evenness index ( $\left.\mathrm{J}^{\prime}\right)$ was maximum in Krishnarjuni pond (o.98) and minimum in Gireejaban pond (o.92) (Table-2). Interestingly, in winter the lowest evenness index was found in Gireejaban pond, whereas the pond showed highest evenness index in summer and rainy seasons (Fig.-3).

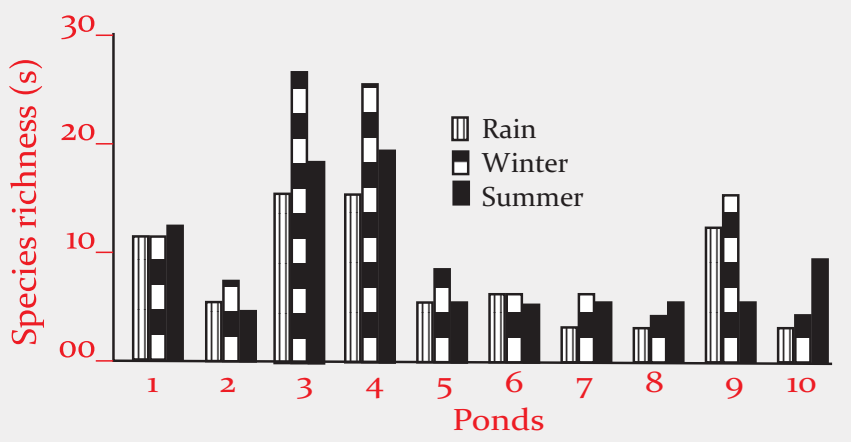

Figure-1: Species richness in wetlands of Ratanpur area during Jan. 2013 to Dec. 2014

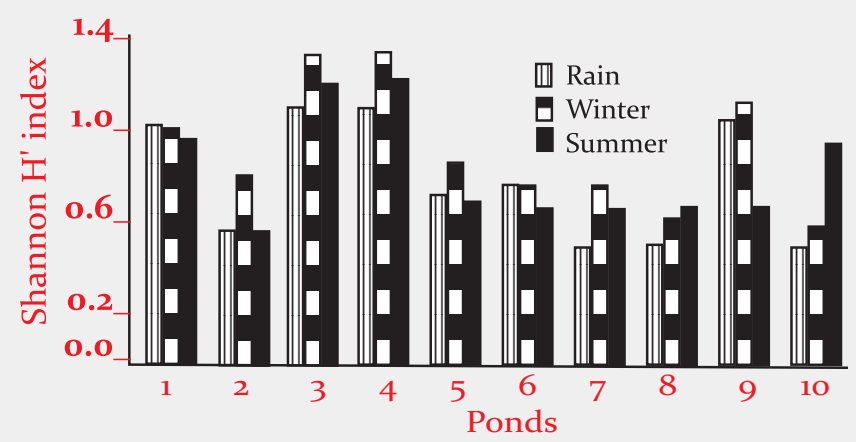

Figure- 2: Shannon Diversity index in wetlands of Ratanpur area during Jan. 2013 to Dec. 2014

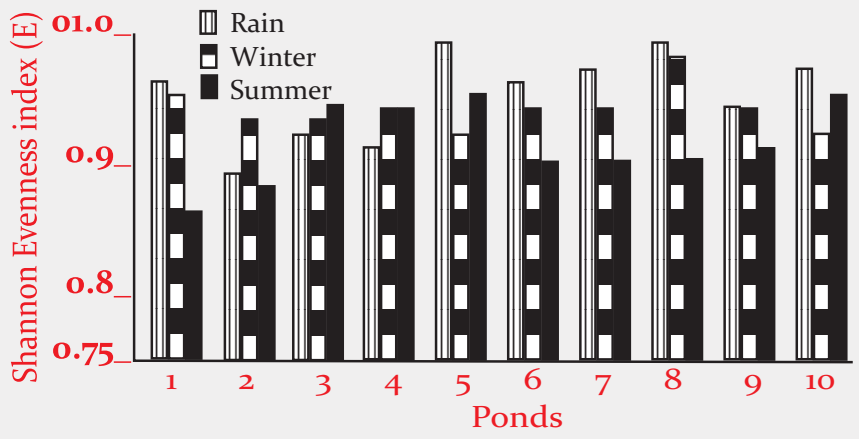

Figure- 3: Species evenness index (E) in wetlands of Ratanpur area during Jan. 2013 to Dec. 2014

\section{Discussion :}

In our study, an avian survey was carried out to record the diversity, distribution, and status of wetland birds in the ten perennial ponds of Ratanpur area. A total of 4572 birds were recorded in all the ten selected ponds of Ratanpur over a period of two years suggesting their wider distribution and adaptability to wetland ecosystem even with the changing environment and anthropologic influence. The higher number and species were recorded in Bikma and Dulhara ponds which are the larger water bodies of the region, perennial and less from anthropogenic activity. The lowest number of species was found in Krishnarjuni may be due to its small sized, situated in between the densely populated city and has greater anthropogenic disturbances. The wetland size influences the species richness and abundance of waterbirds (Froneman et al., 2001; Paracuellos \& Telleria, 2004). Many studies have reported changes in species diversity with high species richness in less disturbed habitat as compared to disturbed habitat (Marsden, 1997; Aggrawal et al., 2015). The season has great influence on diversity and density of bird population (Bhatt et al., 2009). Seasonal fluctuation of birds occurs due to change in weather condition or fluctuation in food availability and habitat quality (Norris \& Marra, 2007). The results our study revealed that the winter season had maximum avian diversity and distribution as compared from summer and rainy seasons and corroborates to the study of Manohara et al. (2016) who attributed this to suitable climate, vegetation, food and less anthropogenic activity. In the rainy and summer season residential wetland avian species dominated while during the winter season, diversity increased due to the addition of various migratory avian species (Rajashekara \& Venkatesha, 2014). In our study, total six winter visitor, one each monsoon and summer visitor water birds were recorded.

Species richness, density, and diversity of bird population are frequently used as indicators to determine the habitat quality (Pandiyan et al., 2013). In our study, the order Ciconiiformes showed maximum diversity (9 species) with the presence of residential heronry birds along with a chief winter migratory Asian Openbill Strok, Anastomus oscitans. The Bubulcus ibis (620), Ardeola grayii (520), Ixobrychus cinnamomeus (303) and Egretta garzetta were the dominant species at Ratanpur wetland areas. Similar results were reported in Kopara reservoir, Bilaspur by Rahalkar et al. (2012). Sharma \& Vishwakarma (2014) reported abundance of Ardeola grayii, Ergetta garzetta, Phalacrocorax niger, Nycticorax nycticorax, Dendrocygna javanica, Nettapus coromandelianus, Metopedius indicus, Vanellus indicus, Gallinula chloropus, Tachybaptus ruficollis in Gidhwa and Parsada wetlands in Bemetra, Chhattisgarh. Our observation evidenced that the ponds which were sacred or away from the town (Bikma, Bairagban, Dulahara, Gireejaban, Maharaiya) were inhabited by large number of avian species while the pond situated near settlement areas or polluted 


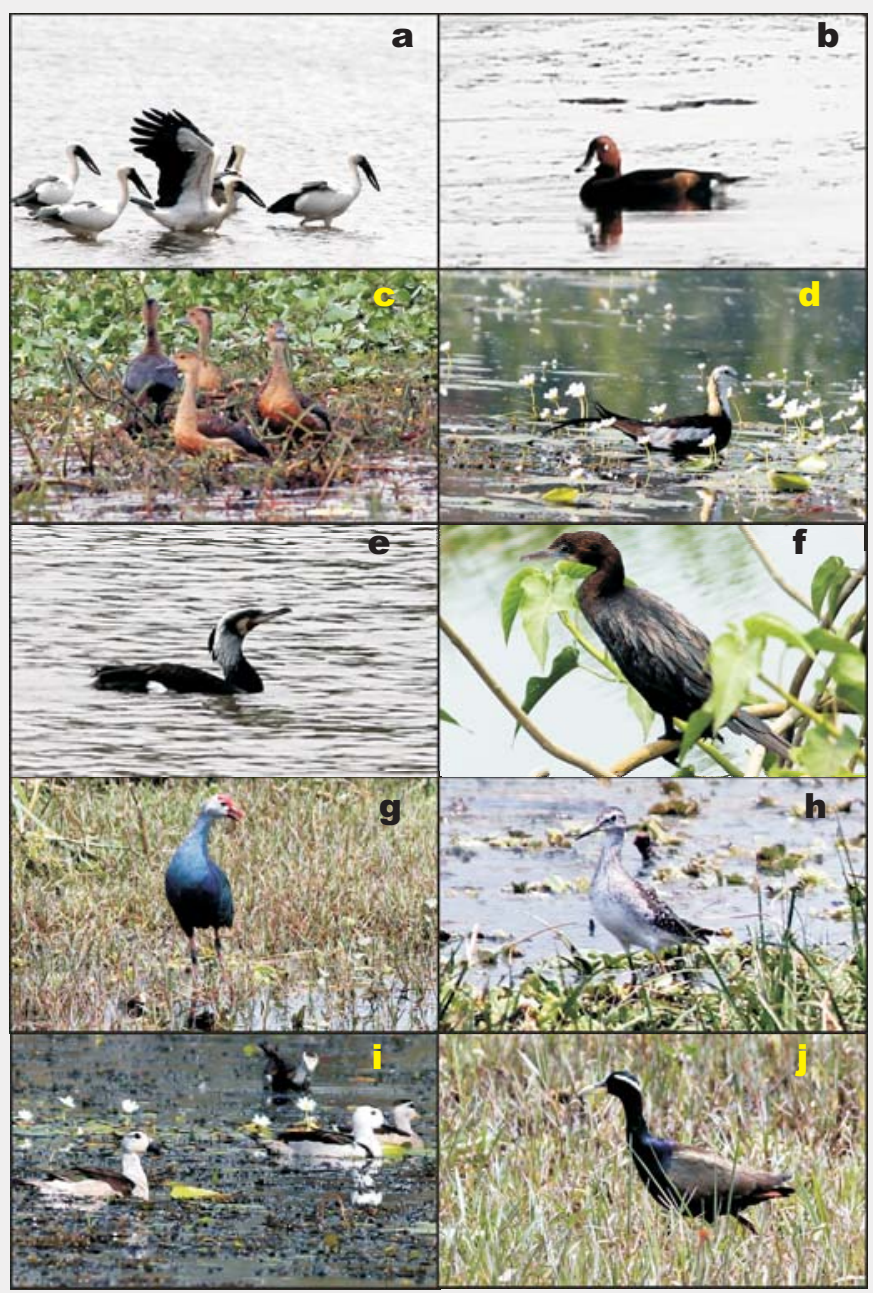

Plate-2: Szome notable wetland bird species captured during spcies. a-Anastomus oscitans, b-Aythya nyroca, c-Dendrocygna javanica, d-Hydrophasianus chirurgus, e-Phalacrocorax carbo, fPhalacrocorax niger, g-Porphyrio porphyria, h-Tringa ochropus, iNettapus coromandelianus, $\mathrm{j}$-Metopidius indicus.

(Bhedimuda, Jagannath, Kaira, Krishnarjuni, Ratneshwar) showed less diversity and were generally occupied by residential avian species mostly heronry birds. Therefore, the maximum species richness was observed in Bikama and Dulahara pond and minimum in Bhedimuda. Such fluctuation of the population helps to understand whether the area is normal or polluted. In our study, it was found in Bikma, Bairagban, Dulahara, and Maharaiya ponds that were unpolluted. Its maximum numberwas found in Bikma and Dulahara. Phalacrocorax carbo was found only in Jagannath pond during summer season in a very low frequency.The presence and absence of wetland birds may indicate the ecological condition of the particular area (Rajpar \& Zakaria, 2011). The fifty percent of the wetlands are under the tremendous anthropogenic pressure (Sulaiman et al., 2014). The anthropogenic activities and developmental measures in and around ponds are remarkably affecting wetland birds. Illegal hunting, fishing practices, deforestation and water pollution were the major threats for wetland avian fauna (Khan \& Ali, 2014; Mistry \& Mukherjee, 2015). The wetlands of Ratanpur are surrounded by agricultural area offering suitable roosting and breeding site for wetland avifauna to increase its density, abundance, and diversity. However, the ecosystem and existing avian diversity of some of the wetlands in the region are under anthropogenic pressure that may directly affect the avifauna in future.

\section{Conclusion :}

Our study provides useful information about the assessment of wetland ecosystem using wetland birds. Out of twenty nine species, one near threatened species was also recorded. Many of these wetlands are used for the collection of lotus, water lily leaves and for flowers and fruits that causes the habitat destruction in respect to wetland avian species. Few ponds were filled by the garbage, waste materials and even suffering from encroachment by the local people. Hunting of avian fauna and habitat modification were also noticed within the study area. Various religious idol immersions during the festival time also pollute these wetlands. Thus, to sustain the avian diversity of these wetland areas some necessary step should be taken by the local administration to make aware the inhabitants of this region about the importance of avian species in the wetland ecosystem.

\section{Acknowledgements:}

The authors are thankful to Dr. A. K. Roy Mahato, Scientist, Gujrat Institute of Desert Ecology, Kachchha, Gujarat for designing our research protocol and encouraging continuously during the work.

\section{References:}

Aggarwal, A., Tiwari, G. \& Harsh, S. (2015): Avian diversity and density estimation of birds of the Indian Institute of Forest Management campus, Bhopal, India, J. Threat. Taxa, 7(2);6891-6902.

Ali, S. (2003): The book of Indian birds. 13th revised ed. Pub. by: Bombay Natural History Society, India. $326 \mathrm{p}$.

Ali, S. \& Ripley, S.D. (1995): Handbook of the Birds of India and Pakistan. Pub. by: Oxford University Press, India.

Bhatt, P.I. Cristopher, S.S. \& Hosetti, B.B. (2009): Avifaunal diversity of Anekere wetland, Karkala, Udupi district, Karnataka, India. L. Environ. Biol., 30(6):1059-1062.

Buckland, S.T., Anderson, D.R., Burnhan, K.P., Lake, J.L., Borchers, D.L. \& Thomas, L. (2004): Advance distance sampling; estimating abundance of biological populations. Pub. by: Campman and Hall, London. 440 p.

Chandra, K. \& Singh, R.K. (2004): Avifauna of Madhya Pradesh and Chhattisgarh. Zoos'print J., 19(7):1534-1539.

Chandra, K., Dutta, S.K., Gupta, R.P. \& Raha, A. (2015): Diversity and Conservational Status of Avifauna in Bastar Plateau of Chhattisgarh, India. Ambient Sci., 2(1):31-43.

Deepa, R.S. \& Ramachandra, T.V. (1999): Impact of urbanization in the interconnectivity of wetlands. In: Proceedings of the 
National Symposium on Remote Sensing Applications for Natural Resources: Retrospective and perspective, (Jan,1999) organized by Indian Society of Remote Sensing, Bangalore, India.

Deshkar, S., Rathod, J.\& Padate, G. (2010): Avifaunal diversity and water quality analysis of an inland wetland. L. Wetlands Ecol., 4:1-32.

Fornemann, A., Mangnall, M., Little, R., \& Crowe, T. (2001): Waterbird assemblages and associated habitat characteristics of farm ponds in the Western Cape, South Africa, Biodiv. Conserv., 10(2):251-270.

Gibbs, J.P. (1993): The importance of small wetlands for the persistence of local populations of wetland-associated animals. Wetlands, 13(1):25-31.

Grimmett, R., Inskipp, C. \& Inskipp, T. (2006): Pocket guide to the birds of the Indian sub-continent. Pub. by: Oxford University Press, India.384 p.

Hossain, M.L., Jaman, M.F. \& Sarker, S.U. (2004): Diversity of herpeto-mammalian fauna and their conservation issues in Hatiya Island, Bangladesh. Trop. Biodiv., 8 (2):71-78.

IUCN (2014): IUCN Red List of threatened species. IUCN, Gland, Switzerland.

Khan, B. N. \& Ali, Z. (2014): Assessment of bird fauna, occurrences, status, diversity indices and ecological threats at Mangla Dam, AJK from 2011 to 2014. L. Anim. Plant Sci., 25(3Sp2):397403.

Kumar, P. \& Gupta, S.K. (2009): Diversity and abundance of wetland birds around Kurukshetra, India. Our Nat., 7(1):187192.

Kumar, A., Kankane, P.L. \& Baqri, Q.H. (2006): Geo-spatial atlas for the wetland birds of Thar Desert, Rajasthan. Pub. by: Zoological Survey of India. 202 p.

Majumdar, N. (1984): On a collection of birds from Bastar district, M.P. in: Record Zoological Survey of India, Occ. Paper, 59:1-54.

Mankandan, R. \& Pittie, A. (2001): Standardised common and scientific names of the birds of the Indian Subcontinent, Buceros, 6(1):1- 40 .

Manohara, G., Harisha,M.N. \& Hosetti, B.B. (2016): Status, diversity and conservation threats of migratory wetland birds in Magadi bird sanctuary, Gadag district, Karnataka, India. I. Entomol. Zool. Stud., 4(4):265-269.

Marsden, S.J. (1997): Changes in bird abundance following selective logging on Seram, Indonesia. Conserv. Biol., 12(3):605-611.

Mistry, J. \& Mukherjee (2015): Status and threats of waterbirds in Ahiran lake, Murshidabad, West Bengal, India. Int. J. Plant Anim. Environ. Sci., 5(2):59-64.

Norris, D.R. \& Marra, P.P. (2007): Seasonal interactions, habitat quality and population dynamics in the migratory birds. The Condor, 109(3):535-547.

Okes, N.C., Hockey, P.A.R. \& Cumming, G.S. (2008): Habitat use and life history as predictors of bird responses to habitat change. Conserv. Biol., 22(1):151-162.
Pandiyan, J., Naresh, B. \& Nagarajan, R., (2013): Salt pans-alternate foraging and roosting habitats for waterbirds, ecosystem services and functions of birds. Ecosystem Services and Functions of Birds, Proceedings of the Second International Conference on Indian Ornithology, at: Salim Ali Centre for Ornithoogy and Natural History, Coimbatore, India.

Paracuellos, M. (2006): How can habitat selection affect the use of a wetland complex by waterbirds? Biodiv. Conserv., 15(4):4569-4582.

Paracuellos, M. \& Telleria, J.L. (2004): Factors affecting the distribution of a water bird community: The role of habitat configuration and bird abundance. Waterbirds, 27(4):446453 .

Rahalkar, S. Dabhadkar, K. \& Tiwari, A. (2012): Study on avian fauna of Kopara reservoir, Bilaspur (C.G.). Contemp. Res. India, 2(2):23-25.

Rajpar, M.N. \& Zakaria, M. (2011): Bird species abundance and their correlationship with microclimate and habitat variables at natural wetland reserve, Peninsular Malaysia. Int. J. Zool., Article ID 758573 .

Rajashekara, S. \& Venkatesha, M.G. (2014): Eco-spatial and temporal variation in waterbirds composition and their relationship with habitat characteristics of urban lakes of Bengaluru city, India. Int. J. Adv. Res., 2(7):6o-8o.

Ramamurthy, V. \& Rajakumar, R. (2014): A study of avifaunal diversity and influences of water quality in the Udhayamarthandapuram Bird Sancturary, Tiruvapur district, Tamil Nadu, India. Int. J. Innov. Res. Sci. Eng. Technol., 3(1):8851-8858.

Rendon, M.A., Green, A.J., Aquilera, E. \& Almaraz, P. (2008): Status, distribution and long- term changes in the water bird community wintering in Doñana, South-west Spain, Biol. Conserv., 141(5)1371-1388.

Rosser, A.M. \& Mainka, S.A., (2002): Over exploitation and species extinctions. Conserv. Biol., 16(3) 584-586.

Sangode, V., Chavhan, P., Meshram, H. \& Roy, P. (2015): Avifaunal diversity of Durg, Chhattisgarh state, J. Entomol. Zool. Stud., 3(2):166-168.

Sharma, D., Vishwakarma, A. \& Yadav, K.C. (2014): The water birds of Gidhwa \& Parsada wetlands, Nandghat, Bemetara, Chhattisgarh (India), Int.J. Sci. Res. Pub., 4(10):1-8.

Sulaiman, I.M., Apeverga, P.T., Ringim, A.S. \& Ibrahim, K.M. (2014): Effects of anthropogenic activities on bird diversity and abundance at Hadejia-Nguru wetlands, Nigeria. Int. J. Res. Stu. Zool., 2(10):546-551.

Urfi, A.J., Sen, M., Kalam, A. \&Megnathan, T. (2005): Counting birds in India: methodologies and trend, Current Sci., 89(12); 1997-2003.

Vishwakarma, A., Hemrom, A. \& Yadav, K.C. (2014): Status of terrestrial and wetland birds in Kawardha,Kabirdham district in Chhattisgarh, India. Int. J. Scient. Res. Pub., 4(10):1-7.

Vishwakarma, A. (2015): Anonymous bird Asian Open bill stork of Chhattisgarh, India. Int. J. Multidisc. Res. Dev., 2(2):618-621. 